\title{
EVALUATION AND VERIFICATION \\ OF SYNCHRONIZATION OF BUSINESS CYCLES \\ OF CONSUMER PRICE INDEX OF ENERGY \\ BETWEEN POLAND AND OECD-EUROPE OR EU-28
}

\section{ELŻBIETA SZARUGA}

University of Szczecin, POLAND

e-mail: elzbieta.szaruga@usz.edu.pl

RECEIVED
ACCEPTED
JEL
CLASSIFICATION

KEYWORDS consumer price index of energy, business cycles, spectral analysis, synchronization

ABSTRACT The article presents the problem of business cycles of consumer price index of energy between Poland and two grouping of states (OECD-Europe and EU-28). The aim of the article is to assess the level of synchronization of business cycles of consumer price index of energy in Poland and OECD-Europe or EU-28. The main hypothesis was formulated: business cycles of consumer price index of energy in OECD-Europe or the EU-28 have a significant impact on the formation of business cycles of consumer price index of energy in Poland, which results from their strong synchronization. In the paper used spectral and cross-spectral methods, as well as the TRAMO/SEATS method and the Hodrick-Prescott filter for business cycles estimation. The research was conducted on the example of Poland, OECD-Europe and EU-28 on the basis of secondary data of consumer price index of energy from the OECD.Stats (2018) database. Monthly time series from January 1996 to December 2017 were used. Two dominant cycles were identified in all surveyed units (66-months and 33-months). As a result of the conducted research, coherence between 79-97\% between business cycles of consumer price index of energy in Poland and EU-28 and 52-83\% between those cycles in Poland and OECD-Europe was obtained. In both cases the amplitude of the business cycles of consumer price index of energy in Poland was lower than in those groups. Longer cycles (50/52-66) of country groups were overtake of similar business cycles in Poland, while for shorter cycles (33-50/52) there was a reverse relation.

\section{Introduction}

The article concerns an extremely important issue of synchronization of business cycles between Poland and OECD-Europe and EU-28. On the one hand, synchronization demonstrates the level of economic integration with these groupings, but on the other hand it is the determinant of making decisions and creating long-term forecasts. 
The aim of the article is to assess the level of synchronization of business cycles of consumer price index of energy in Poland and OECD-Europe or EU-28.

For the purposes of the article, the main hypothesis was formulated: business cycles of consumer price index of energy in OECD-Europe or the EU-28 have a significant impact on the formation of business cycles of consumer price index of energy in Poland, which results from their strong synchronization. In the paper used spectral and cross-spectral methods, as well as the TRAMO/SEATS method and the Hodrick-Prescott filter for business cycle estimation. The article consists of 3 parts: literature review, methodology and results of empirical research.

\section{Litepature review}

Synchronization of business cycles is important, especially in the light of economic integration processes or from the point of view of common and optimal areas of economic cooperation (Sethapramote, 2015). Business cycles affects in the many directions, but there are three main reasons causing the synchronization cycles (Mejía-Reyes, Rendón-Rojas, Vergara-González, Aroca, 2018, p. 2; Canova, Dellas, 1993):

- combined disturbances or shocks, including: oil distress, global stagnation, recessions or revivals, economic and political discordance (even clashes) could affect the orientation of business cycles,

- in the case of a similar structure of production of various areas, sectoral shocks may affect shifts of individual phases of business cycles,

- international shocks may be shifted from outside (especially small open economies integrated with bigger economies may be particularly vulnerable), which affects the synchronization of business cycles.

The most interesting papers in which these surfaces have recently been touched include the paper by, among others: Ahlborn and Wortmann (2018), Gong and Kim (2018), Juvenal and Monteiro (2017), Karadimitropoulou (2018), Li (2017), Lukmanova and Tondl (2017), Miles (2017), Szaruga (2017). The methodological workshop of these researchers is diverse. Due to the purpose of the article, attention has been paid only to spectral methods.

On the problems of synchronization of business cycles using spectral methods wrote Chionis and Leon (2009). They examined the synchronization of Polish and European economic cycles of GDP, finding the dominant one with the frequency of 0.045 cycles (equivalent to 5.5 years). Ductor and Leiva-Leon (2016) also used spectral methods to evaluate business cycle synchronization. Their research conducted at the world's major economies in the post-Great Moderation. An in-depth study on the synchronization of business cycles in the euro area was conducted by Skrzypczyński (2006). In empirical research, he also used spectral and cross-spectral analysis, as well as the object estimating business cycles, proving that the euro zone cycles are strengthened and deepened by member states.

For the purpose of this article, spectral methods have also been used, but the assessment and verification of business cycles synchronization has been carried out on the example of Poland, OECD-Europe and UE-28. The approach presented is the closest to Skrzypczyński (2006) and Chionis and Leon (2009). However, the presented research in the further part of the article can be freely extended by further research and methodical threads.

\section{Methods and data}

The research was conducted on the example of Poland, OECD-Europe and EU-28 on the basis of secondary data of consumer price index of energy from the OECD.Stats (2018) database. Monthly time series from January 
1996 to December 2017 were used. The choice of time and subject range is intentional because of the assumptions and limitations of the methods used and the substantive premises.

The data has been cleared of seasonal fluctuations and decomposed using the TRAMO/SEATS method. During the estimation, a trend-cycle component was obtained (so-called Henderson's trend-cycle component), which was then subjected to filtration. Henderson's trend-cycle component has been decomposed separately for the trend and cycle by the Hodrick-Prescott filter (frequency response $\lambda=14,400$ ). The resulting cycle component was examined for stationarity using the Augmented Dickey-Fuller test.

Subsequently, cross-correlation was examined between the cycles with the maximum delay of 12 months. The investigation was extended by spectral analysis of cycles, analyzing the longest amplitude for the periodogram values. Based on them, dominant cycles were isolated and then the cycle synchronization was verified based on cross-spectral analysis, examining coherence, gains and phase spectrum. The results of the conducted examination are presented below.

\section{Results}

Figure 1 presents business cycles of consumer index price of energy (after decomposition with Hodrick-Prescott filter).

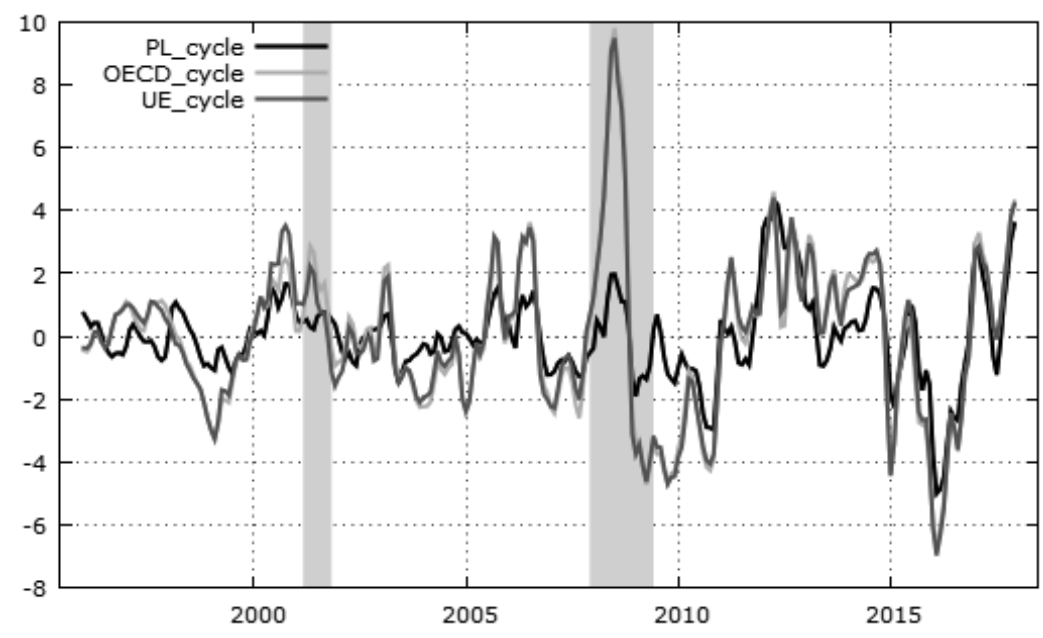

NBER recessions were marked by shaded fields.

Figure 1. Cycles of consumer price index of energy on the example of Poland, EU-28 and OECD-Europe from January 1996 to December 2017

Source: own elaboration based on OECD.Stats (2018).

From Figure 1 it can be concluded that the amplitudes of business cycles for OECD-Europe and EU-28 are more similar than those in Poland. However, after 2015, the Polish business cycles began to adapt to the OECD-Europe and EU-28 cycles. 
In order to determine whether decomposed cycles have stationary properties, it was necessary to examine with Augmented Dickey-Fuller test (ADF).

Table 1. ADF test results for cycles of consumer price index of energy in Poland, OECD-Europe and EU-28 from January 1996 to December 2017

\begin{tabular}{lccc}
\hline \multicolumn{1}{c}{ Item } & ADF & Optimal number of lag & Conclusion \\
\hline PL_cycle & $-0.0758^{* * *}$ & 8 & $\mathrm{I}(0)$ \\
OECD_cycle & $-0.0638^{* * *}$ & 8 & $\mathrm{I}(0)$ \\
EU_cycle & $-0.0611^{* * *}$ & 8 & $\mathrm{I}(0)$ \\
\hline
\end{tabular}

${ }^{*},{ }^{* *},{ }^{* *}$ reject the null hypothesis I(1) at the significance level of $10 \%, 5 \%, 1 \%$ respectively.

Maximum number of lag $=12$. The modified AIC criterion was applied.

Source: own computations based on OECD.Stats (2018).

Based on the results of the ADF test, one could refute the null hypothesis about the lack of stationarity in favor of the hypothesis assuming the stationarity of the business cycles studied. The optimal number of lag was 8 months. In next step, evaluated cross correlation coefficients between the analyzed business cycles in Poland and OECD-Europe or EU-28 (Table 2).

Table 2. Cross-correlation coefficients between the cycles of consumer price index of energy in Poland and the cycle of consumer price index of energy in OECD-Europe or EU-28 from January 1996 to December 2017

\begin{tabular}{lccccccccccc}
\hline \multicolumn{1}{c}{ Time } & $\mathrm{t}-\mathbf{1 0}$ & $\mathrm{t}-\mathbf{9}$ & $\mathrm{t}-\mathbf{8}$ & $\mathrm{t}-\mathbf{7}$ & $\mathrm{t}-\mathbf{6}$ & $\mathrm{t}-\mathbf{5}$ & $\mathrm{t}-\mathbf{4}$ & $\mathrm{t}-\mathbf{3}$ & $\mathrm{t}-\mathbf{2}$ & $\mathrm{t}-\mathbf{1}$ & $\mathrm{t}$ \\
\hline OECD & 0.13 & 0.15 & 0.16 & 0.18 & 0.21 & 0.27 & 0.36 & 0.47 & 0.61 & 0.72 & $\mathbf{0 . 7 6}$ \\
EU & 0.14 & 0.16 & 0.17 & 0.19 & 0.23 & 0.28 & 0.38 & 0.49 & 0.62 & 0.74 & $\mathbf{0 . 7 7}$ \\
\hline \multicolumn{1}{c}{ Time } & $\mathrm{t}$ & $\mathrm{t}+1$ & $\mathrm{t}+2$ & $\mathrm{t}+3$ & $\mathrm{t}+4$ & $\mathrm{t}+5$ & $\mathrm{t}+6$ & $\mathrm{t}+7$ & & & \\
\hline OECD & $\mathbf{0 . 7 6}$ & 0.67 & 0.55 & 0.43 & 0.32 & 0.23 & 0.17 & 0.14 & & \\
EU & $\mathbf{0 . 7 7}$ & 0.68 & 0.55 & 0.43 & 0.32 & 0.22 & 0.16 & 0.13 & & \\
\hline
\end{tabular}

The table contains cross-correlation coefficients statistically different from zero, assuming $p$-value $<0.05$.

Source: own computations based on OECD.Stats (2018).

As can be seen from the Table 2, the correlation coefficients were statistically significant from the 7-month delay to the 10-month overtake. However, the highest correlation coefficient was recorded when the delay/overtake was 0.

Figure 2-5 (periodograms) show the spectrum of business cycles of consumer price index of energy, respectively for Poland, OECD-Europe and EU-28 in all analyzed time range (from Janurary 1996 to December 2017). 


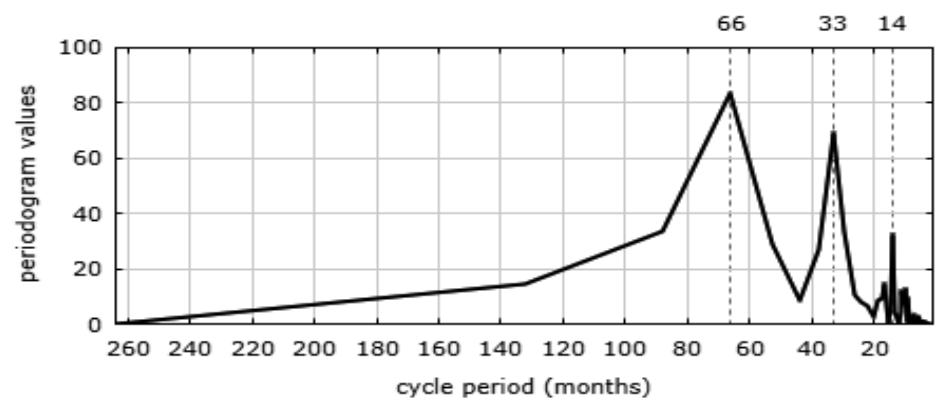

Figure 2. Spectrum of cycles of consumer price index of energy in Poland (1996:01-2017:12)

Source: own elaboration based on OECD.Stats (2018).

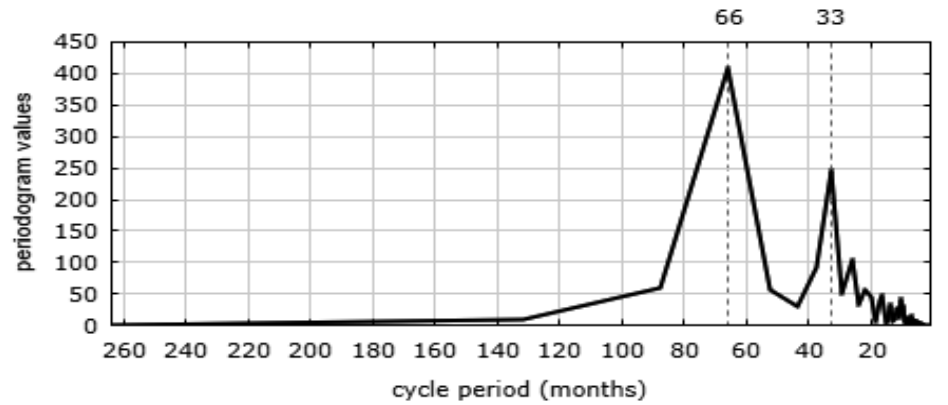

Figure 3. Spectrum of cycles of consumer price index of energy in OECD-Europe (1996:01-2017:12)

Source: own elaboration based on OECD.Stats (2018).

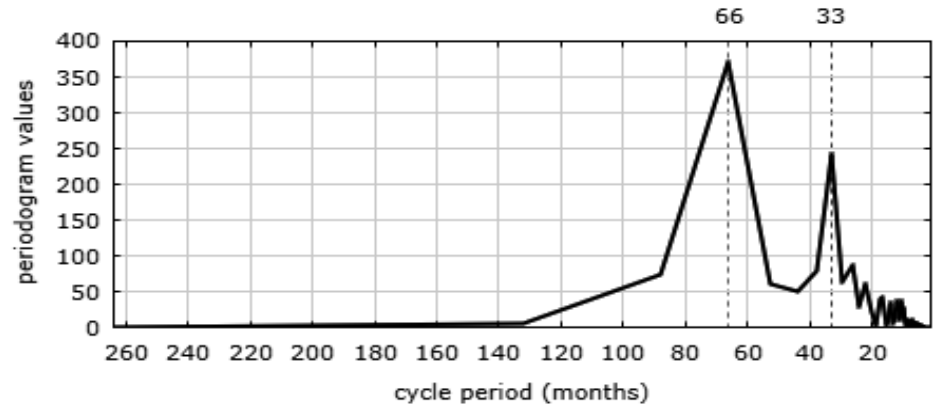

Figure 4. Spectrum of cycles of consumer price index of energy in EU-28 (1996:01-2017:12)

Source: own elaboration based on OECD.Stats (2018). 
On the basis of periodograms (the highest amplitudes of periodogram values) one could determine two dominant cycles in Poland, OECD-Europe and EU-28: 66 months long (5.5 years) and 33 months (2.75 years) long. In Poland, an additional dominant cycle of 13.89 months was recorded. Due to the purpose of the study, only the 66-month and 33-month business cycles were examined.

Figure 5 presents a cross-spectral analysis between business cycles for Poland and OECD-Europe, and Figure 6 - between business cycles for Poland and EU-28. Dependent variable was business cycle of Poland, and independent variables was in first case - business cycle of OECD-Europe, in second case - business cycle of EU-28.
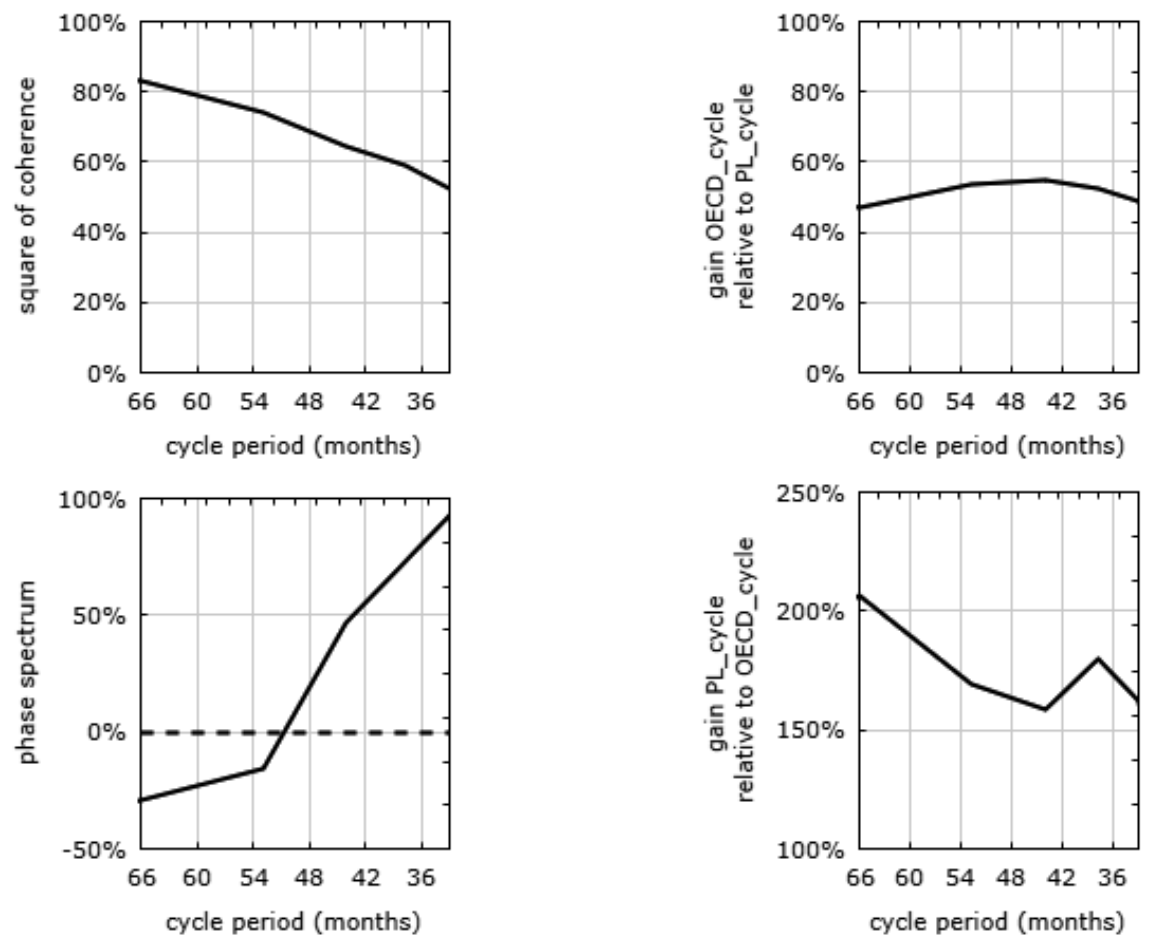

Figure 5. Measures of cross-spectral analysis between the cycle of consumer price index of energy in Poland and OECDEurope

Source: own elaboration based on OECD.Stats (2018).

Figure 5 shows that there was a high coherence between the cycle in OECD-Europe and Poland at the level of approx. $52 \%$ to over $83 \%$. Greater coherence was for longer cycles. Amplitudes of fluctuations were higher in OECD-Europe than in Poland. Poland rather adapted to the cycles at OECD-Europe. However, phase shifts indicate that longer cycles (50-66 months) in OECD-Europe (negative values) were ahead of similar cycles in Poland. Cycles (33-50 months) were delayed in the OECD towards Poland. 

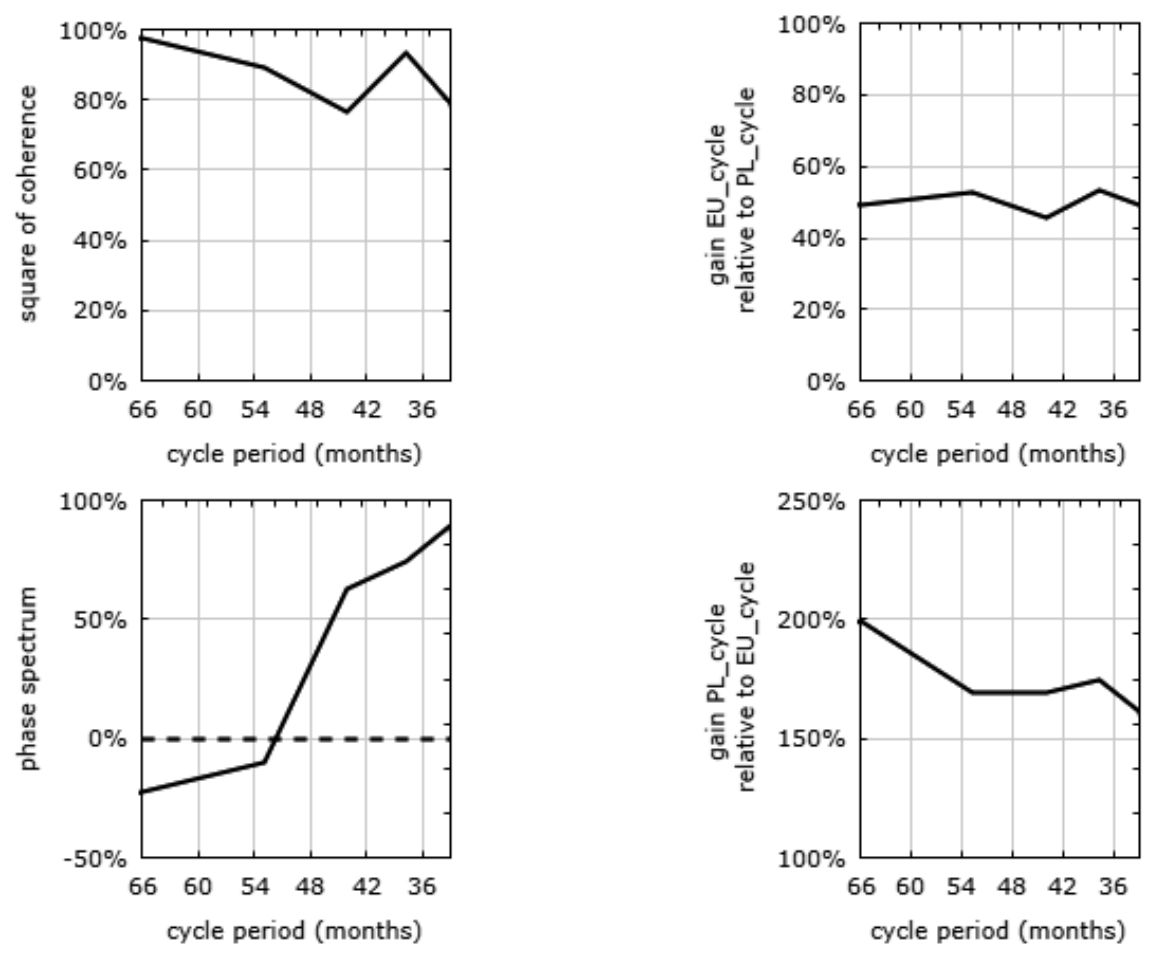

Figure 6 . Measures of cross-spectral analysis between the cycle of consumer price index of energy in Poland and EU-28 Source: own elaboration based on OECD.Stats (2018).

Figure 6 shows that there was very high coherence between the cycle in the EU-28 and Poland at the level of about $79 \%$ to about $97 \%$. Greater coherence was for longer cycles than shorter ones. It is an extremely high coherence in the entire frequency range of business cycles. It is much higher than between Poland and OECD-Europe. Amplitudes of fluctuations were higher EU-28 than in Poland. Poland rather adapted to the cycles in EU-28. However, phase shifts indicate that longer cycles (52-66 months) in EU-28 (negative values) were ahead of similar cycles in Poland. Cycles (33-52 months) were delayed in the EU-28 in relation to Poland, as in the case of OECD-Europe and Poland.

\section{Conclusions}

Summing up, the cycles in Poland are strongly synchronized with the OECD-Europe and EU-28 cycles, but more strongly with the EU-28 than the OECD-Europe. In addition, longer cycles are more synchronized than shorter ones. On the basis of the results, one can say with full conviction that business cycles are synchronized with the EU-28 and OECD-Europe cycles. However, delays and anticipations also play a role. It was found that the maximum delay is 7 months and the advance is 10 months. Applying this to the observation that there are two dominant 66-month and 33-month cycles, one can assume the appropriate moment for synchronization is the period of \pm 17 months. It seems that the purpose of the article has been achieved and the hypothesis verified. 


\section{References}

Ahlborn, M., Wortmann, M. (2018). The core-periphery pattern of European business cycles: A fuzzy clustering approach. Journal of Macroeconomics, 55, 12-27. DOI: 10.1016/j.jmacro.2017.08.002.

Canova, F., Dellas, H. (1993). Trade interdependence and the international business cycle. Journal of International Economics, 34 (1-2), 23-47. DOI: 10.1016/0022-1996(93)90065-6.

Chionis, D., Leon, C. (2009). Synchronization of the Polish and European Business Cycles. The Journal of Economic Asymmetries, 6 (1), 119-139. DOI: 10.1016/j.jeca.2009.01.009.

Ductor, L., Leiva-Leon, D. (2016). Dynamics of global business cycle interdependence. Journal of International Economics, 102, 110127. DOI: 10.1016/j.jinteco.2016.07.003.

Gong, C., Kim, S. (2018). Regional Business Cycle Synchronization in Emerging and Developing Countries: Regional or Global Integration? Trade or Financial Integration? Journal of International Money and Finance, In press, accepted manuscript. DOI: 10.1016/j.jimonfin.2018.02.006.

Juvenal, L., Monteiro, P. (2017). Trade and synchronization in a multi-country economy. European Economic Review, 92, 385-415. DOI: 10.1016/j.euroecorev.2016.06.005.

Karadimitropoulou, A. (2018). Advanced economies and emerging markets: Dissecting the drivers of business cycle synchronization. Journal of Economic Dynamics and Control, In press, corrected proof. DOI: 10.1016/j.jedc.2018.01.029.

Li, L. (2017). The impact of intra-industry trade on business cycle synchronization in East Asia. China Economic Review, 45, 143-154. DOI: $10.1016 / j . c h i e c 0.2017 .07 .004$.

Lukmanova, E., Tondl, G. (2017). Macroeconomic imbalances and business cycle synchronization. Why common economic governance is imperative for the Eurozone. Economic Modelling, 162, 130-144. DOI: 10.1016/j.econmod.2017.01.004.

Mejía-Reyes, P., Rendón-Rojas, L., Vergara-González, R., Aroca, P. (2018). International synchronization of the Mexican states business cycles: Explaining factors. The North American Journal of Economics and Finance, In press, corrected proof. DOI: 10.1016/j. najef.2018.01.009.

Miles, W. (2017). Has there actually been a sustained increase in the synchronization of house price (and business) cycles across countries? Journal of Housing Economics, 36, 25-43. doi:10.1016/j.jhe.2017.02.002.

OECD.Stats (2018,). OECD Statistics. Retrieved from http://stats.oecd.org (February 26).

Sethapramote, Y. (2015). Synchronization of business cycles and economic policy linkages in ASEAN. Journal of Asian Economics, 39, 126-136. DOI: 10.1016/j.asieco.2015.06.003.

Skrzypczyński, P. (2006). Analiza synchronizacji cykli koniunkturalnych w strefie euro. Materiały i Studia NBP, 210, 1-48.

Szaruga, E. (2017). Effects of energy price shocks on business cycles in industrial production of consumer and capital goods: Evidence from Poland in the post-crisis period. In: M. Gotowska, P. Antoszak (eds.), Gospodarka i społeczeństwo wobec wyzwań przyszłości. Aspekt makroekonomiczny. Bydgoszcz: Wydawnictwa Uczelniane Uniwersytetu Technologiczno-Przyrodniczego w Bydgoszczy.

Cite this article aS: Szaruga, E. (2018). Evaluation and verification of synchronization of business cycles of consumer price index of energy between Poland and OECD-Europe or EU-28. European Journal of Service Management, 3 (27/1), 321-328. DOI: 10.18276/ ejsm.2018.27/1-41. 